\title{
Current Account Dynamics in OECD Countries and in the New EU Member States: An Intertemporal Approach
}

\author{
Matthieu Bussière \\ European Central Bank \\ Marcel Fratzscher \\ European Central Bank \\ Gernot J. Müller \\ European Central Bank
}

\begin{abstract}
This paper investigates the large current account deficits observed in most new EU member states using an intertemporal model. The standard model is extended to include: (1) the persistence of current account positions and (2) the relevance of the fiscal balance. Specifically, a closed form solution for consumption in the presence of habit persistence and liquidity constraints is derived, yielding a dynamic model for the current account where fiscal deficits have an effect. The model is estimated for a panel of 33 countries. A key finding is that current accounts in most new EU member states are broadly in line with their structural current account positions.
\end{abstract}

- JEL classification: F32, F41

- Keywords: Current account, Habit persistence, Liquidity constraints, Transition economies

\footnotetext{
*Corresponding address: Matthieu Bussière, Marcel Fratzscher, European Central Bank, Kaisertrasse 29, D-60311, Frankfurt am Main, Germany, Fax ++49 691344 7666; E-mails: Matthieu.Bussiere@ecb.int (corresponding author); Marcel. Fratzscher@ecb.int

'Gernot.Mueller@wiwi.uni-frankfurt.de Mertonstrasse 17, PF 94, D-60054 Frankfurt am Main, Germany. 


\section{Introduction}

The past decade has seen a strong increase in theoretical and empirical work on the determinants and dynamics of the current account. Much of the rise of this literature has come from the conceptual progress made in open economy macroeconomics, and in particular on the intertemporal approach to the current account that was initially proposed by Sachs (1981) and thoroughly extended by Obstfeld and Rogoff $(1995,1996)$. The standard intertemporal model of the current account considers the current account from the saving-investment perspective and features an infinitely lived representative agent who smoothes consumption over time by lending or borrowing abroad. For example, this approach suggests that a country would run a current account deficit if income is temporarily low or investment temporarily high. This standard intertemporal current account (ICA) model represents an appropriate tool to analyze current account balances in the new EU member states ${ }^{1}$ : the huge catching up potential of these countries, as well as their strong investment needs could both justify the large current account deficits observed in these countries in the past decade.

The empirical literature on the current account has followed two directions. On the one hand, several tests have established evidence in favour of the baseline model using different testing strategies ${ }^{2}$. On the other hand, several papers have tried to identify the long-run determinants of the current account drawing from a broader class of intertemporal models, i.e. variations of the infinitely lived representative agent model, but also overlapping generation (OLG) models. Two stylized facts have emerged from this literature, which are not accounted for in the standard representative agent framework. First, current account balances seem to be highly persistent: many empirical studies find that the present current account is influenced by its lagged value, without providing a formal argument why this is the case. Second, the fiscal balance is often found to have significant effects on the current account, whereas in the standard representative agent framework Ricardian equivalence holds ${ }^{3}$.

\footnotetext{
The ten countries that joined the European Union in 2004 are here referred to as "new EU member states"; in the period prior to accession, they were referred to as "acceding countries".

${ }^{2}$ Sheffrin and Woo (1990), for example, employ a present value test and find some support of the model. Another methodology suggested by Glick and Rogoff (1995) assesses the impact of productivity shocks both on investment and the current account. They find that the restrictions implied by the ICA model are not rejected by the data for a sample of G-7 countries.
} 
The objective of this paper is twofold. First, the paper is an attempt to bridge the gap between the theoretical and the empirical work on the determinants of the current account. We add two features to the standard representative agent framework in order to provide a formal argument for the effect of the fiscal balance and for the use of a dynamic model of the current account. Specifically, we relax the representative agent assumption by considering two types of agents. While the first type of agent is assumed to be liquidity constrained, the second type is characterized by optimizing Ricardian behaviour and external habit formation.

The second intended contribution of the paper is to analyze the current account dynamics of the ten new EU member states. To our knowledge, this is the first attempt in the literature to provide an analysis of the current account dynamics for all new EU member states. The issues of the determinants and the dynamics of the current account in these countries are of substantial policy relevance. The results of the empirical model allow us to provide estimates for the structural current account levels, i.e. estimates of what current account positions these countries will converge to in the medium-run. Our concept of structural current account positions is based on the idea that permanent changes in the determinants of the current account do not immediately materialize, but - in the presence of habit formation -- will only gradually impact on the current account position. The structural current account positions are therefore calculated on the basis on the implied long-run coefficients of our dynamic model.

A word of caution is in order at this stage. The purpose of the paper is to analyze the behaviour of current accounts in the medium- to long-term from an intertemporal perspective. It should be stressed that current account positions which appear justified from such a perspective can only materialize subject to the constraints implied by international capital flows. In other words, a country that is growing rapidly and is able to repay its debt - i.e. a country that is solvent - may nevertheless not be able to finance a particular current account deficit if investors are not willing to provide the required funds - i.e. if the country is liquidity constrained. ${ }^{4}$

${ }^{3}$ Chinn and Prasad (2003) estimate an empirical model of the current account determination using a panel of 89 countries. One of their main findings is a positive relationship between the current account and the fiscal surplus. Similarly, Bussière, Driver and Chortareas (2003) find effects of the fiscal surplus on the current account. Moreover, in a dynamic specification of the model they find substantial persistence in the current account.

${ }^{4}$ Milesi-Ferretti and Razin (1998), for instance, provide an analysis of current account reversals in the short-run, while Bussière and Fratzscher (2002) analyse the role of liquidity ratios and financial variables in bringing about currency crises and current account reversals. 
Hence, one key difficulty for obtaining the determinants of current account movements in the medium- to long-run is the issue of how to control for transitory shocks affecting current accounts in the short-term. Since such shocks are frequently related to financing issues, reflected in currency crises or banking crises, countries that experienced severe financial crises are not included in the sample. This requires excluding Asian and Latin American emerging economies since these experienced severe financial crises during the 1990s. Using this criterion leaves us with a sample of 33 countries for our empirical exercise: the ten new EU Member states plus Bulgaria and Romania, and 21 OECD countries. ${ }^{5}$

The paper employs and compares different empirical methodologies - various panel data, instrumental variable (IV) and Generalized Method of Moments (GMM) techniques - to estimate a dynamic panel data model for the current account. The joint evidence from these estimators supports the intertemporal model and the variables identified in the theoretical framework appear to have a significant impact on the current account. Specifically, we find a strong effect of the lagged current account and a significant effect of the fiscal balance. Moreover, we find a substantial effect of relative per capita income, such that countries that are relatively poorer are more likely to run larger current account deficits. Moreover, expansionary fiscal policies also raise the current account deficit, confirming that Ricardian off-set is incomplete. Several sensitivity tests are carried out, in particular, we test for and cannot reject the hypothesis of slope homogeneity between the OECD countries and the new EU member states.

Based on the different dynamic estimators, the paper then derives the structural current account positions for each of the 33 countries. A first important finding is that the different estimators are robust and yield mostly very similar estimates for the structural current accounts. The second main result is that the structural determinants of our intertemporal model are capable of explaining well past movements in current accounts for most of the countries in our sample. The third main empirical finding is that the substantial current account deficits in most new EU member states were in 2002 broadly in line with the estimated structural current account positions for these countries. This is an important finding from a policy perspective, because it suggests that the sizeable current account deficits in most new EU member states do indeed make sense from an intertemporal perspective,

\footnotetext{
${ }^{5}$ Also some of the OECD and transition countries, such as the Czech Republic in May 1997, experienced some form of financial distress, but these cases were mostly relatively minor ones with no large adjustments in the current accounts of the affected countries.
} 
stressing the enormous potential of these countries to catch up with the more mature OECD economies in the coming decades.

The remainder of the paper is organized as follows. The next section outlines our ICA model with liquidity constraints and habit persistence. Section III describes the sample used for the estimation of the model and provides some summary statistics. It also gives some justification for the estimation strategy. Section IV provides the empirical results, derives the structural current account positions, discusses some examples. Section 5 concludes.

\section{Theoretical Framework}

In this section, we develop a model for the current account, adding two features to the standard ICA model: liquidity constraints and habit formation. Both features concern private consumption behaviour and eventually, imply a richer specification of current account determination. Thus, the current section involves two steps. In a first step, we discuss our assumptions on private consumption behaviour and derive a closed form solution for aggregate consumption. In a second step, we substitute for private consumption in the definition of the current account and derive a dynamic model for the current account.

\section{A. The Consumption Function}

We consider a small open economy, which faces a constant world interest rate. All variables are in per capita terms. Output, investment and public spending are exogenous as are taxes, which are assumed to be lump-sum. Our first modification of the standard ICA model concerns the possible heterogeneity of the population. We assume that the economy is populated by a continuum of individuals normalized to one. However, there are only two different types of individuals in the economy. The first type of individuals spends its disposable income in every period, i.e. income less investment and taxes, and is thus liquidity constrained in the sense of, e.g., Campbell and Mankiw (1991). The other type of individuals is characterized by its optimizing behavior with respect to the intertemporal allocation of consumption. In order to distinguish both types we refer to nonRicardian and Ricardian consumers, respectively, since only the second type of individuals behaves in accordance with the Ricardian equivalence proposition which characterizes the standard ICA model. ${ }^{6}$ 
Specifically, we assume that non-Ricardian consumers make up for a fraction $\lambda \in[0,1]$ of the population. Hence, aggregate consumption $\bar{C}_{t}$ is given by the weighted average of non-Ricardian consumption $C_{t}^{N R}$ and Ricardian consumption $C_{t}^{R}$, with weights $\lambda$ and $1-\lambda$, respectively:

$$
\bar{C}_{t}=\lambda C_{t}^{N R}+(1-\lambda) C_{t}^{R}
$$

By assumption non-Ricardian consumption equals disposable per capita income, i.e. output $Y_{t}$ less investment $I_{t}$ and taxes $T_{t}$ :

$$
C_{t}^{N R}=Y_{t}-I_{t}-T_{t}
$$

Our second modification of the standard ICA model concerns the behavior of Ricardian agents. While we assume that this type of agents is characterized by optimizing behavior, we assume external habits, i.e., we assume intra-period utility to depend not on actual consumption as such, but on the degree by which actual consumption exceeds some fraction $\gamma$ of last period's aggregate consumption. This particular habit specification goes back to Abel (1990) and is referred to as "catching up with the Joneses". Note how the assumption of habit formation in general offers a way to accommodate for why consumers' sense of welfare is apparently more related to changes in consumption than to its absolute level. ${ }^{7}$

Specifically, we assume that Ricardian consumption is the solution to the following intertemporal optimization problem faced by a representative Ricardian agent:

$$
\operatorname{Max} E_{t}\left[\sum_{s=t}^{\infty} \beta^{s-t} u\left(C_{s}^{R}-\gamma \bar{C}_{s-1}\right)\right]
$$

\footnotetext{
${ }^{6}$ Recently, Galí, Lopez-Salido and Valles (2002) also introduce "liquidity constraints" in order to investigate the effect of government spending on private consumption. Their terminology is "optimizing" and "rule of thumb" consumers for Ricardian and non-Ricardian consumers, respectively. "Rule of thumb" (non-Ricardian) consumers do not smooth consumption but spend disposable income. Galí et al. suggest the following interpretations of this kind of behaviour: myopia, lack of access to capital markets, fear of saving, ignorance of intertemporal trading opportunities. However, Galí et al. assume that rule of thumb consumers are not subject to taxation.

${ }^{7}$ For a more recent application, see, e.g., Campbell and Cochrane (1999). Internal habits are considered within the ICA framework by Gruber (2002).
} 
s.t.

$$
B_{s+1}^{P}=(1+r) B_{s}^{P}+Y_{s}+T_{s}-I_{s}-C_{s}^{R}
$$

i.e., Ricardian agents maximize the expected infinite sum of utility discounted by $\beta$, where intratemporal utility is a function of $C_{s}^{R}-\gamma \bar{C}_{s-1}$. The parameter $0<\gamma<1$ captures the degree of habit persistence. $\mathrm{E}_{\mathrm{t}}$ is the expectations operator. Finally, $B_{t}^{P}$ represents the net financial assets held by a representative Ricardian agent at the end of period $t-1$ and the fixed return $r$ is the net return between periods $t-1$ and $t$. Iterating (4) and imposing a "no-Ponzi game" condition yields the intertemporal budget constraint of an representative Ricardian agent,

$$
E_{t} \sum_{s=t}^{\infty} \frac{C_{s}^{R}}{(1+r)^{s-t}}=(1+r) B_{t}^{P}+E_{t} \sum_{s=t}^{\infty} \frac{Y_{s}-T_{s}-I_{s}}{(1+r)^{s-t}}
$$

Under the assumption that individual consumption decisions have a negligible effect on aggregate consumption we obtain the first order condition for (3) by substituting for $C_{s}^{R}$ using (4) and maximizing life-time utility with respect to $\mathrm{B}_{\mathrm{s}+1}$. For every period $s \geq t$ the following Euler condition must hold:

$$
u^{\prime}\left(C_{s}^{R}-\gamma \bar{C}_{s-1}\right)=(1+r) \beta E_{t}\left\{u^{\prime}\left(C_{s+1}^{R}-\gamma \bar{C}_{s}\right)\right\}
$$

We further assume that the intratemporal utility function $\mathrm{u}$ is quadratic in $C_{s}^{R}-\gamma \bar{C}_{s-1}$ and that the subjective discount factor $\beta$ equals the (world) market discount factor $1 /(1+r)$ in order to obtain:

$$
C_{s}^{R}-\gamma \bar{C}_{s-1}=E_{t}\left(C_{s+1}^{R}-\gamma \bar{C}_{s}\right)
$$

In order to derive a closed form solution for Ricardian consumption we relate the first order condition (6) to the intertemporal budget constraint (5). After some manipulations (see appendix in Bussière, Fratzscher and Müller, 2004) we obtain the consumption function of a representative Ricardian agent:

$$
C_{t}^{R}=\frac{\gamma}{1+r} \bar{C}_{t-1}+\left(1-\frac{\gamma(1-\lambda)}{1+r}\right) r B_{t}^{P}+\left(1-\frac{\gamma}{1+r}\right) \frac{r}{1+r} E_{t} \sum_{s=t}^{\infty} \frac{Y_{s}-T_{s}-I_{s}}{(1+r)^{s-t}}
$$

Aggregate consumption, in turn, is obtained by substituting for $\mathrm{C}_{-}{ }^{\wedge} \mathrm{NR}$ and 
C_^t in (1) using (2) and (7), respectively:

$$
\begin{gathered}
\bar{C}_{t}=\lambda\left(Y_{t}-T_{t}-I_{t}\right)+(1-\lambda) \frac{\gamma}{1+r} \bar{C}_{t-1}+(1-\lambda)\left(1-\frac{\gamma(1-\lambda)}{1+r}\right) r B_{t}^{P} \\
+(1-\lambda)\left(1-\frac{\gamma}{1+r}\right) \frac{r}{1+r} E_{t} \sum_{s=t}^{\infty} \frac{Y_{s}-T_{s}-I_{s}}{(1+r)^{s-t}}
\end{gathered}
$$

Finally, we consider the government budget constraint,

$$
B_{t+1}^{G}=(1+r) B_{t}^{G}+T_{t}-G_{t}
$$

where $\mathrm{G}_{\mathrm{t}}$ denotes public spending and $B_{t}^{G}$ denotes government net assets in per capita terms. Iterating and imposing a "no-Ponzi game" condition gives the intertemporal government budget constraint:

$$
E_{t} \sum_{s=t}^{\infty} \frac{G_{s}}{(1+r)^{s-t}}=(1+r) B_{t}^{G}+E_{t} \sum_{s=t}^{\infty} \frac{T_{s}}{(1+r)^{s-t}}
$$

The net per capita stock of foreign assets of the economy as a whole, $\mathrm{B}_{\mathrm{t}}$, is given by the sum of net private assets and net government assets. Note, moreover, that no assets are held by non-Ricardian agents, such that we have the following relationship:

$$
B_{t}=(1-\lambda) B_{t}^{P}+B_{t}^{G}
$$

\section{B. Current Account Dynamics}

Following Obstfeld and Rogoff (1995) we define the current account as the increase in residents' claims on foreign income, i.e., $C A_{t}=B_{t+1}-B_{t}$. In terms of national accounts these net savings of the open economy correspond to the sum of net income (returns on net foreign assets) $\mathrm{rB}_{\mathrm{t}}$ and net output $N O_{t}=Y_{t}-I_{t}-G_{t}$ minus aggregate consumption:

$$
C A_{t}=r B_{t}+N O_{t}-\bar{C}_{t}
$$

By substituting for aggregate consumption using (8), we derive a dynamic 
model of current account determination (see appendix in Bussière, Fratzscher and Müller, 2004):

$$
\begin{gathered}
C A_{t}=(1-\lambda) \gamma C A_{t-1}+\lambda\left(T_{t}+r B_{t}^{G}-G_{t}\right)+\frac{\gamma(1-\lambda)}{1+r} \Delta N O_{t} \\
(1-\lambda)\left(1-\frac{\gamma}{1+r}\right)\left(N O_{t}-E_{t} \overline{\overline{N O}}_{t}\right)
\end{gathered}
$$

where we define $\overline{\overline{X_{t}}}$ as the permanent value of variable $\mathrm{X}_{\mathrm{t}}$, i.e., the hypothetical constant level of a time varying variable with the same present value as the variable itself, see Obstfeld and Rogoff (1996):

$$
\overline{\overline{X_{t}}}=\frac{r}{1+r} \sum_{s=t}^{\infty} \frac{X_{s}}{(1+r)^{s-t}}
$$

such that $N O_{t}-E_{t} \overline{\overline{N O}}$ t provides a measure for how much the actual net output exceeds "permanent" level.

Note how our modifications of the standard ICA model enter in equation (13). In the standard case, i.e., without habits and liquidity constraints, we have $\lambda=0$ and $\gamma=0$, such that $C A_{t}=N O_{t}-E_{t} \overline{\overline{N O}}_{t}$. Essentially, the standard ICA model implies that only country-specific deviations of net output from its expected permanent level have an impact on the current account of a particular economy. If, on the other hand, global shocks change the expected permanent level of net output in all economies, any desire to change savings will be offset by the induced change in the world interest rate. As a consequence, if output (investment or public spending) in a given country is temporarily above the permanent level, the net foreign asset position of the economy increases (decreases), i.e., it runs a current account surplus (deficit). Such net savings serve to stabilize consumption at the permanent level. Under the assumption that net output is exogenous, the consumption behavior of private agents drives the current account against the background of a time-varying resource flow. ${ }^{8}$

The presence of the fiscal surplus $T_{t}+r B_{t}^{g}-G_{t}$ is a straightforward implication following from the introduction of liquidity constraints $(\lambda>0)$. The way public spending is financed directly impacts on the disposable income and thus on the consumption of liquidity constrained (non-Ricardian) agents. A fiscal surplus

${ }^{8}$ See, e.g., Sachs (1982) and Glick and Rogoff (1995) for an explicit model of output determination. 
induces a current account surplus, since it lowers disposable income of nonRicardian agents and thereby aggregate consumption. Therefore aggregate savings in the economy increase. Our modification of the standard ICA model thus provides a straightforward way to account for the so-called "twin deficits".

The assumption of external habits adds additional structure to the current account model. Notably, it induces current account dynamics by making the current account dependent on its past level. The degree of dependence is given by the weight of Ricardian agents in the population $(1-\lambda)$ and the measure of habit persistence $\gamma$. In addition, the change in net output also enters the current account equation as a result of habit formation in private consumption.

To sum up, equation (13) provides a formal argument for a dynamic current account model which also allows for the impact of fiscal deficits. It will guide our empirical exploration.

\section{Data and Estimation Issues}

\section{A. Sample and Summary Statistics}

Our empirical analysis of current account dynamics is based on annual timeseries data for 33 countries including all 10 new EU member states and the two accession countries Bulgaria and Romania (see Table 1 below). In the following we refer to the whole group as accession countries. While our focus is on the current account of accession countries we use a larger sample, because reliable time series for the accession countries are short. In fact, for accession countries we use data from 1995 onwards thereby excluding the early transition period in most of the accession countries. In addition we include 21 OECD countries in our panel using time series data from 1980-2002. In the following we refer to this group of countries as OECD countries. ${ }^{9}$

Our main source is the World Economic Outlook database (WEO) provided by the IMF. For some variables, like the real exchange rate, we used other sources (ECB) and own calculations. We normalize the data by using GDP ratios, except in case of output (or income) itself.

The theoretical model (13) implies that the deviation of the actual components

\footnotetext{
${ }^{9}$ This group includes: Australia, Austria, Belgium, Canada, Denmark, Finland, France, Germany, Greece, Ireland, Italy, Japan, Netherlands, New Zealand, Norway, Portugal, Spain, Sweden, Switzerland, UK, US.
} 
of net output from permanent level have an impact on the current account. These components are gross output (or income), investment and public spending. The permanent level is not directly observable, but the cross-country average of our sample provides a natural proxy for the permanent value. Specifically, we construct the variable relative income using the log deviation of the per capita income from the (time-varying) cross country average. The maintained hypothesis is that the countries in our sample converge in terms of PPP-adjusted per capita income, such that differences in per capita income across countries provide a rationale for current account imbalances. Of course, richer countries may also expect income to grow in the future. However, what is relevant for the current account is relative growth of per capita income, since changes in the global interest rates will prevent all countries from borrowing against future income growth. Implicitly we are thus assuming that richer countries will grow more slowly, such that their relative income growth is actually negative. In order to attenuate this assumption, we use the OECD average of per capita income to construct the variable relative income in the case of OECD countries. Only for the accession countries we use the average of the whole sample.

We also construct variables to proxy for the effects of the other components of net output on the current account. In the regressions below we use the investment ratio and the public spending ratio after subtracting the OECD average of these ratios. In the following we use these relative ratios when we refer to investment and public spending ratio.

Table 1 reports the average of the current account balance as percentage of GDP in EU accession countries for the period 1995-2002. Apart from Slovenia, all countries run substantial current account deficits throughout the period, with deficits above 10 percent in Estonia, Lithuania, Malta and the Slovak Republic. The unweighted average of the current account deficit for all accession countries is above five percent, while the average current account balance for the OECD countries is around one percent surplus for the period 1995-2002.

Table 1 also reports the average fiscal balance as percentage of GDP for the sample period. On average, accession countries run a fiscal deficit of 2.7 percent as compared to a fiscal deficit of 1.1 percent in OECD countries.

In addition, Table 1 reports the PPP-adjusted per capita income, the investment and the public spending ratios. The average PPP-adjusted per capita income across the whole sample and over the period 1995-2002 is 18683 USD. Most of the accession countries have higher investment ratios than the OECD sample average (18 
Table 1. New EU Member States 1995-2002*

\begin{tabular}{lccccccc}
\hline & \multicolumn{2}{c}{ current account } & fiscal balance & income & investment & public spending \\
\cline { 2 - 7 } & mean & Min & max & mean & mean & mean & mean \\
\hline Bulgaria & -2.3 & -6.1 & 4.3 & -2.5 & 5218 & 12.3 & 38.1 \\
Cyprus & -4.1 & -6.6 & -1.7 & -3.5 & 16698 & 14.9 & 36.3 \\
Czech Rep. & -4.8 & -7.1 & -2.1 & -1.4 & 13815 & 24 & 41.6 \\
Estonia & -8 & -12.1 & -4.4 & -0.1 & 7959 & 22.6 & 40.3 \\
Hungary & -4.2 & -6.2 & -1.4 & -3 & 11154 & 19.2 & 48.4 \\
Latvia & -6.7 & -9.8 & -0.4 & -2.2 & 6232 & 19.7 & 40.8 \\
Lithuania & -7.8 & -11.9 & -4.8 & -3.8 & 6632 & 19.2 & 35.1 \\
Malta & 7.5 & -13.4 & -3.2 & -7.1 & 14174 & 22 & 46.7 \\
Poland & -3.3 & -7.1 & 2 & -3 & 8575 & 19.3 & 43.4 \\
Romania & -5 & -6.8 & -3.4 & -2.9 & 6521 & 18.5 & 34.2 \\
Slovak Rep. & -6.5 & -10.2 & 1.9 & -2.7 & 10037 & 27.1 & 44.4 \\
Slovenia & -0.5 & -3.3 & 1.7 & -0.6 & 15473 & 20 & 41.8 \\
\hline
\end{tabular}

*All variables in percent of GDP, except income which is per capita income (USD, PPP-adjusted)

percent), while the public spending ratio varies around the OECD average of 45 percent.

In order to illustrate some basic relationships, Figure 1 displays cross-country plots of the average current account against the fiscal surplus, the per capita income, the investment and the public spending ratios. Except for the public spending ratio the plots are in line with the hypothesized relationships of the intertemporal model. Fitting regression lines also gives significant coefficients, except for the public spending ratio. The $\mathrm{R}^{2}$ are 19 percent, 50 and 21 percent for the fiscal surplus, relative income and the investment ratio, respectively. However, this evidence is based on unconditional correlations and on the between information only. The estimation results below, on the other hand, are supposed to establish complementary and more rigorous evidence based on the within information of our panel.

Finally, we also have to meet concerns regarding the stationarity of our time series. The time series of the accession countries are too short, however, for unit root tests. We therefore do panel unit root tests for the OECD subsample only, where the data go back to 1980 such that we can rely on 23 time-series observations for 21 countries. We employ both the Im-Pesaran-Shin (2003) panel unit root test and the Levin and Lin test as discussed in Levin, Lin and Chu (2002). Using zero to two lags, we find somewhat mixed evidence, but are able to reject to null of a unit root for most lag lengths. Specifically, using one lag, we can reject 
Figure 1. Cross Country Relationships - Averages 1995-2002

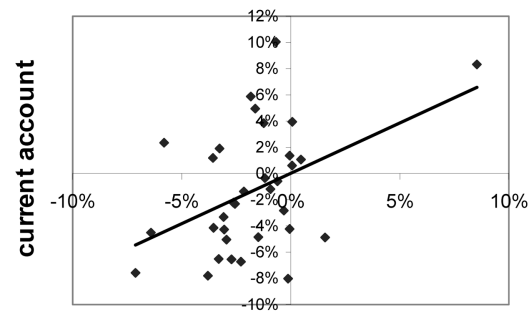

fiscal balance

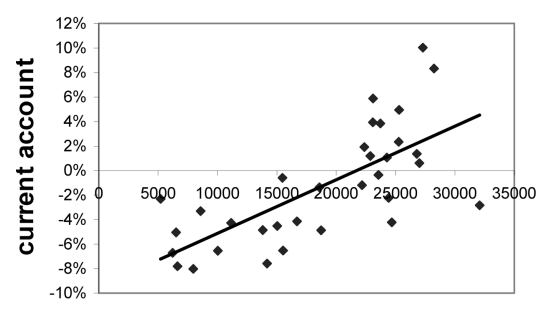

per capita income

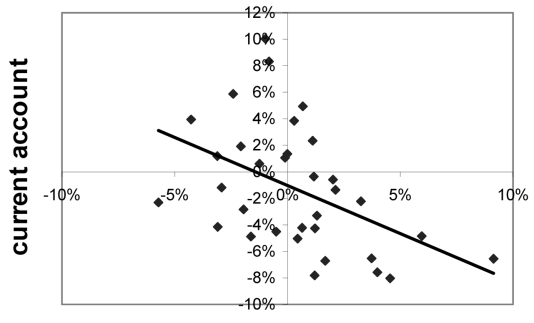

investment ratio

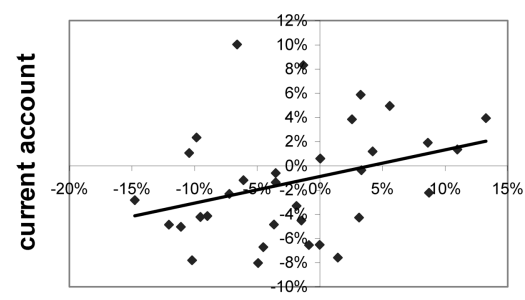

public spending ratio

the null for all series, i.e. current account to GDP, fiscal balance to GDP, relative income, investment ratio and public spending ratio.

\section{B. Estimation Strategy}

Before turning to the estimation a few remarks concerning the estimation framework are in order. We are interested in estimating the following dynamic model:

$$
y_{i t}=\alpha y_{i t-1}+\beta X_{i t}+u_{i t}
$$

where $\mathrm{i}=1 \ldots \mathrm{N}$ and $\mathrm{t}=1 \ldots \mathrm{T}$ denote the cross sectional and time dimensions, respectively. The dependent variable $y_{i t}$ is the current account to GDP ratio. The model is dynamic due to the presence of the lagged dependent explanatory variable $\mathrm{y}_{\mathrm{i}, \mathrm{t}-\mathrm{1}}$. Other explanatory variables $\mathrm{X}_{\mathrm{it}}$ are the change in net output, the fiscal surplus, relative income, the relative investment ratio and the relative ratio of public expenditure. As usual, we assume that the error term $u_{i t}$ consists of a country specific effect $\mathrm{MU}_{\mathrm{i}}$, which we assume to be fixed, and a residual error term epsilon $_{\text {it }}$ with zero mean. We make the assumption that $\mathrm{MU}_{\mathrm{i}}$ is fixed, because the requirement that country specific random effects are uncorrelated with the regressors is unlikely to be met in our panel.

In static models with fixed effects (i.e. $\alpha=0$ ) the Within Group (or LSDV for least squares dummy variable) estimator provides consistent estimates for $\beta$. It eliminates the fixed effects by means of a within group transformation of the data, 
whereby the original observations are expressed as deviations from their average across time. However, in a dynamic model, this transformation induces a correlation of order $1 / \mathrm{T}$ between the transformed lagged dependent variable and the transformed error term. As a result, the LSDV estimator is inconsistent for finite $\mathrm{T}$ and $\mathrm{N} \rightarrow \infty$, see Nickell (1981). Given that, at least for the accession countries, our panel is rather short (overall we have: $8 \leq \mathrm{T} \leq 22$ and $\mathrm{N}=33$ ) the standard LSDV estimator may only be used with some caution.

An alternative transformation to account for fixed effects is to first-difference the data, which also induces a correlation between the transformed lagged dependent variable $\Delta \mathrm{y}_{\mathrm{t}-1}$ and the transformed error term $\Delta \varepsilon_{\mathrm{it}}$. However, since this transformation does not introduce all realized disturbances into the transformed error term, $\Delta \mathrm{y}_{\mathrm{t}-1}$ may be instrumented by $\Delta \mathrm{y}_{\mathrm{t}-2}$. This is the first differenced Two Stage Least Squares estimator that was suggested by Anderson and Hsiao (1982). In the following we refer to this estimator as IV estimator. The IV estimator provides consistent estimates when N,T or both tend to infinity. We therefore use all observations (i.e. the unbalanced panel) when we use the IV estimator to estimate the baseline specification.

An alternative to the IV estimator is the GMM estimator proposed by Arellano and Bond (1989), which - based on the same transformation- exploits more orthogonality conditions using a (possibly) larger set of instruments. Consistency for this estimator is established for $\mathrm{N} \rightarrow \infty$, while the number of overidentifying restrictions increases with $\mathrm{T}$, since the lagged dependent variable is used as an instrument (in levels). In order to maintain a sensible relationship between $\mathrm{N}=33$ and the number of overidentifying restrictions we limit the number of lagged dependent variables which are used as instruments to 1 and use the balanced panel, i.e. data for all 33 countries from 1995-2002. Specifically, we impose the moment conditions $\mathrm{E}\left(\Delta \mathrm{u}_{\mathrm{it}} \mathrm{y}_{\mathrm{it}-2}\right)=0$ for $\mathrm{t}=1997 \ldots 2002$, which provides us with 5 overidentifying restrictions ( 6 identifying restrictions less one to identify $\alpha$ ). Consequently, we use $\chi^{2}$ distribution with 5 degrees of freedom when we employ the Sargan test for the estimated model below. In the GMM specification we have included only one lag of the dependent variable on the right-hand side, which is consistent with our theoretical model.

Both alternatives to the LSDV estimator are not without disadvantages. While these estimators have superior asymptotic properties, they are less precise than the LSDV, see Kiviet (1995). Bond (2002) also emphasizes that the alternatives to the LSDV estimator may be subject to large finite sample biases, in case the 
instruments are weak. We therefore use all three estimators and base further analysis on the joint evidence.

We find some differences in the point estimates depending on which estimator is used. Eventually, however, we are interested in the long-run relationships implied by the dynamic model, since it provides a measure for the structural current account position, i.e. the current account after cyclical effects have died out and the effect of changes in the fundamentals have fully materialized. In other words, we are interested in the coefficients $\beta /(1-\alpha)$. With respect to these coefficients we find that all three estimators provide qualitatively similar results. Moreover, we may also draw on the results of the between estimator, i.e. estimating the relationship between average or long run values of the variables. ${ }^{10}$

\section{Results and Structural Current Account Positions}

\section{A. Short-Run Dynamics}

Table 2 reports the results of estimating the baseline specification using the LSDV, the IV and the GMM estimator. All estimators provide fairly similar results, but the IV and GMM estimates are less significant. ${ }^{11}$ The $\mathrm{R}^{2}$ are satisfactory for the LSDV and the IV estimator, being 75 and 60 percent, respectively. With respect to the GMM estimates, the Sargan test does not reject the overidentifying restrictions imposed by the model.

All coefficients have the expected sign, except the coefficient on the public spending ratio in the IV and GMM case. Moreover, for all other variables except investment and the change in net output the estimates of the LSDV estimator are within the range given by the IV and the GMM estimator. Against this background, there is no evidence of a possible downward bias of the LSDV estimator, except perhaps in the case of investment. In addition, it is also more robust and estimates the coefficients more tightly than the IV and GMM estimator. In what follows we therefore focus on the LSDV estimator.

Considering the LSDV estimates, we find substantial persistence in the current account dynamics. The coefficient on the lagged current account of 0.5 is broadly

\footnotetext{
${ }^{10}$ See, e.g., Ventura (2003) for an interpretation of the between estimates as long-run relationships.

${ }^{11}$ Note that the number of cross-sections is 33 in all three cases, the time-series observations which are used by the three estimators differ. The maximum number of observations is used by the LSDV estimator: 542. The IV estimator uses 490 and the GMM estimator uses 198 observations.
} 
Table 2. Dynamic Model, Baseline Specification (dependent variable - current account to GDP ratio)

\begin{tabular}{|c|c|c|c|c|c|c|}
\hline & LSDV & & IV & & GMM & \\
\hline lagged current account & $\begin{array}{c}0.578 \\
(0.032)\end{array}$ & $* *$ & $\begin{array}{c}0.708 \\
(0.336)\end{array}$ & $* *$ & $\begin{array}{c}0.302 \\
(0.144)\end{array}$ & $* *$ \\
\hline fiscal surplus & $\begin{array}{c}0.088 \\
(0.037)\end{array}$ & $* *$ & $\begin{array}{c}0.250 \\
(0.079)\end{array}$ & $* *$ & $\begin{array}{c}0.063 \\
(0.111)\end{array}$ & \\
\hline$\Delta$ net_output & $\begin{array}{c}0.410 \\
(0.040)\end{array}$ & $* *$ & $\begin{array}{c}0.398 \\
(0.186)\end{array}$ & $* *$ & $\begin{array}{c}0.186 \\
(0.122)\end{array}$ & \\
\hline rel. income & $\begin{array}{c}0.019 \\
(0.005)\end{array}$ & $* *$ & $\begin{array}{c}0.002 \\
(0.025)\end{array}$ & & $\begin{array}{c}0.022 \\
(0.046)\end{array}$ & \\
\hline investment ratio & $\begin{array}{l}-0.405 \\
(0.046)\end{array}$ & $* *$ & $\begin{array}{l}-0.421 \\
(0.283)\end{array}$ & $* *$ & $\begin{array}{l}-0.684 \\
(0.172)\end{array}$ & $* *$ \\
\hline public spending ratio & $\begin{array}{l}-0.025 \\
(0.032)\end{array}$ & & $\begin{array}{c}0.388 \\
(0.244)\end{array}$ & & $\begin{array}{c}0.027 \\
(0.166)\end{array}$ & \\
\hline $\mathrm{R}^{2}$ or $\chi^{2}(5)^{\mathrm{a}}$ & 0.752 & & 0.598 & & $\begin{array}{c}3.740 \\
(0.587)\end{array}$ & \\
\hline
\end{tabular}

**(*) denotes significance at the 5\% (10\%) level, standard errors in parentheses (a) for LSDV and IV: $\mathrm{R}^{2}$ (within), GMM: Sargan test (p-value)

in line with the findings of the literature, e.g., Chinn and Prasad (2003). It captures the partial adjustment of the current account and can be rationalized by habit formation in the behaviour of private agents. As the current account represents net saving decisions and is thus complementary to consumption decisions, the current account inherits the sluggishness of consumption changes which are due to habit formation. As a result the current account does not fully respond to changes in fundamentals instantaneously. This drives a wedge between the long-run effect of the fundamentals on the current account and their short-run effect that is given by the other coefficients in Table 2. According to our estimates, nine percent of a change in the fiscal surplus is immediately reflected in an increase in the current account position. This confirms the finding of other studies that there is no complete Ricardian off-set of changes in the way the public expenditure is financed. While the impact of the fiscal surplus on the current account may appear somewhat small, it should be emphasized that the implied long-run effect is more than twice as high. The coefficient on the change in net output of around 0.4 can also be rationalized by habit formation. Only $60 \%$ of an increase in net output are consumed, since consumption adjusts only gradually to changes in net output. 40 percent, on the other hand, are saved, i.e. reflected in the current account.

The positive coefficient on relative income indicates that a per capita income 
below the average, will be associated with a current account deficit. A per capita income of 10 percent below the average (of, for instance, 27000 USD in 2002 in OECD countries) lowers the current account by approximately 0.2 percent (note that the long run effect will be more than twice as much). The rationale is that poorer countries are assumed to grow faster than the average and are thus borrowing against future income.

If investment and public spending ratios are above their "permanent" levels of approximately 18 and 45 percent, respectively, they are expected to induce a current account deficit. An increase in these ratios by one percent will lower the current account by 0.4 and 0.03 percent, respectively, since they temporarily reduce the resources available for private consumption. The difference in the coefficients may be partly explained by difference in the perceived persistence of the deviations from the "permanent" values. If investment ratios are more volatile than public spending ratios one would expect a stronger response to change in the investment ratio. Note, however, that the evidence on the effects of public spending is rather weak. Both in the IV and the GMM case the coefficient is insignificant and enters with the wrong sign.

Given the lack of significance for the estimated effect of the public spending ratio, Table 3 (first column) reports an alternative specification, where this variable is dropped. We find that the overall fit improves slightly and that all coefficients are tightly estimated. We therefore use this specification in the following and refer to it as LSDV'. Several reasons could explain this result. In particular, whereas the sample average is a reasonable proxy for the permanent values of income and investment given the maintained assumption of long-term convergence, this may not be the case for public spending. Moreover, Table 3 also carries out some robustness tests, by including the dependency ratio (column 2) and the real exchange rate (column 3 ) into the model. Other authors, using a similar specification, find that the real exchange rate and the dependency ratio matter for the current account, see, e.g., Debelle and Faruqee (1996). ${ }^{12}$ We do not find any evidence, however, for an effect on the current account in the context of our intertemporal model.

Eventually, our interest is the current account positions of the new EU member states. A natural question therefore is whether there is slope heterogeneity in this

\footnotetext{
${ }^{12}$ The real exchange rate enters this regression as deviation from its time series average. As before all variables transformed into deviation from the cross-sectional mean to account for time effects.
} 
Table 3. Dynamic Model, Alternative Specifications (LSDV') (dependent variable - current account to GDP ratio)

\begin{tabular}{|c|c|c|c|c|c|c|}
\hline lagged current account & $\begin{array}{c}0.585 \\
(0.030)\end{array}$ & $* *$ & $\begin{array}{c}0.576 \\
(0.031)\end{array}$ & $* *$ & $\begin{array}{c}0.579 \\
(0.030)\end{array}$ & $* *$ \\
\hline fiscal surplus & $\begin{array}{c}0.104 \\
(0.032)\end{array}$ & $* *$ & $\begin{array}{c}0.108 \\
(0.032)\end{array}$ & $* *$ & $\begin{array}{c}0.105 \\
(0.032)\end{array}$ & $* *$ \\
\hline$\Delta$ net_output & $\begin{array}{c}0.418 \\
(0.038)\end{array}$ & $* *$ & $\begin{array}{c}0.413 \\
(0.038)\end{array}$ & $* *$ & $\begin{array}{c}0.421 \\
(0.039)\end{array}$ & $* *$ \\
\hline rel. income & $\begin{array}{c}0.018 \\
(0.005)\end{array}$ & $* *$ & $\begin{array}{c}0.023 \\
(0.006)\end{array}$ & $* *$ & $\begin{array}{c}0.017 \\
(0.005)\end{array}$ & $* *$ \\
\hline investment ratio & $\begin{array}{l}-0.389 \\
(0.041)\end{array}$ & $* *$ & $\begin{array}{l}-0.380 \\
(0.042)\end{array}$ & $* *$ & $\begin{array}{c}-0.394 \\
(0.041)\end{array}$ & $* *$ \\
\hline dependency ratio & & & $\begin{array}{c}0.035 \\
(0.027)\end{array}$ & & & \\
\hline real exchange rate & & & & & $\begin{array}{c}-0.007 \\
(0.005)\end{array}$ & \\
\hline $\mathrm{R}^{2}$ & 0.765 & & 0.760 & & 0.762 & \\
\hline
\end{tabular}

$* *(*)$ denotes significance at the $5 \%(10 \%)$ level, standard errors in parentheses

particular subsample. Table 4 reports LSDV' estimates which interact the most important regressors with an accession country dummy variable. The overall evidence is in favor of homogeneity. The only interaction term which enters significantly is the fiscal surplus (column 1). We find, however, that this result is driven by Bulgaria and Romania. If we only consider the 10 new EU member states the interaction term is no longer significant. We therefore use the LSDV' model without interaction term in order to calculate the structural current account position in these countries. ${ }^{13}$

Finally, we consider the estimated fixed effects in order to judge the ability of the model to explain the current account dynamics in our panel. A large fixed effect for country i would suggest that the model has some difficulties in explaining the average level of the current account balance in country i. For the 10 new EU member states only 3 countries have fixed effects above one percent, namely -2.5 percent in Cyprus, 1.4 percent in the Slovak Republic and 1.5 percent in Slovenia (see Table 6, column 2 for further details). Considering the whole sample, we also have fairly low fixed effects, except for the U.S. (-2.4 percent) and Switzerland (3.0 percent). Overall, we consider the low fixed effects as additional

\footnotetext{
${ }^{13}$ Dropping all non-OECD countries from the sample yields very similar estimates as the core LSDV' specification; these results are available upon request. The results also proved robust to the removal of outliers (e.g. Switzerland, which on average runs a much larger current account surplus than other countries).
} 
Table 4. Dynamic Model, Interaction Terms (LSDV') (dependent variable - current account to GDP ratio)

\begin{tabular}{lcccccccc}
\hline & \multicolumn{2}{c}{ surplus } & \multicolumn{2}{c}{ surplus' } & \multicolumn{2}{c}{ Relative income } & \multicolumn{2}{c}{ investment } \\
\hline lagged current account & 0.581 & $* *$ & 0.584 & $* *$ & 0.585 & & 0.584 & $* *$ \\
& $(0.030)$ & & $(0.030)$ & & $(0.030)$ & & $(0.030)$ & \\
fiscal surplus & 0.134 & $* *$ & 0.118 & $* *$ & 0.100 & $* *$ & 0.104 & $* *$ \\
& $(0.032)$ & & $(0.031)$ & & $(0.032)$ & & $(0.032)$ & \\
$\Delta$ net_output & 0.339 & $* *$ & 0.410 & $* *$ & 0.420 & $* *$ & 0.418 & $* *$ \\
& $(0.040)$ & & $(0.039)$ & & $(0.038)$ & & $(0.038)$ & \\
rel. income & 0.026 & $* *$ & 0.017 & $* *$ & 0.019 & $* *$ & 0.018 & $* *$ \\
& $(0.005)$ & & $(0.005)$ & & $(0.005)$ & & $(0.005)$ & \\
investment ratio & -0.403 & $* *$ & -0.395 & $* *$ & -0.383 & $* *$ & -0.390 & $* *$ \\
& $(0.041)$ & & $(0.041)$ & & $(0.042)$ & & $(0.044)$ & \\
interaction term & -0.242 & $* *$ & -0.154 & & -0.022 & & 0.012 & \\
& $(0.041)$ & & $(0.043)$ & & $(0.043)$ & & $(0.005)$ & \\
$\mathrm{R}^{2}$ & 0.759 & & 0.760 & & 0.753 & & 0.765 & \\
\hline
\end{tabular}

**(*) denotes significance at the 5\% (10\%) level, standard errors in parentheses

evidence for our model.

\section{B. Structural Current Account Positions}

The aim of the present paper is to derive structural current account positions, i.e. to determine a current account position which can be considered as "normal" from an intertemporal perspective when cyclical effects have died out. We follow the approach suggested in Isard et al. (2001) and calculate the long-run relationships implied by our dynamic model, which are given by $\beta /(1-\alpha){ }^{14}$

In addition, the net output change has to be disregarded when we focus on the long-run relationship. However, we consider that deviations of the investment ratio from the OECD mean may persist for longer periods and are thus taken into account when we calculate the structural current account positions.

Table 5 reports the long-run coefficients which are implied by the dynamic model. We also report the results from the between estimation, which uses the average values for the period 1995-2002 in a cross-country regression. While the implied long-run coefficients of the dynamic (LSDV') model on the fiscal surplus and relative income are close to the between estimates, there is a difference in the

\footnotetext{
${ }^{14}$ They use the term "equilibrium saving-investment position" where we use "structural current account postition".
} 
Table 5. Implied Long-run Relationships / Between Estimates (dependent variable - current account to GDP ratio)

\begin{tabular}{lcccc}
\hline & surplus & surplus & Between & \\
\hline fiscal surplus & 0.209 & 0.251 & 0.376 & $*$ \\
Relative income & & & $(0.227)$ & \\
& 0.045 & 0.043 & 0.055 & $* *$ \\
Investment ratio & & & $(0.014)$ & \\
& -0.960 & -0.937 & -0.499 & $* *$ \\
$\mathrm{R}^{2}$ & & & $0.195)$ & \\
\hline
\end{tabular}

$* *(*)$ denotes significance at the $5 \%(10 \%)$ level, standard errors in parentheses

coefficient on the investment ratio. We therefore use both, the results of the LSDV' and the Between estimator, to calculate structural current account positions.

Table 6 reports the structural positions which are implied by the value of the fiscal surplus, the relative income position and the investment ratio as of 2002 . We also include the long-run value of the fixed effect in the structural current position using the LSDV' estimates. Fixed effects correspond to the average part of the current account that is unexplained by our intertemporal model. We have no reason to assume - from a positive point of view - that this level effect will not persist in the future. Overall, we find that actual current account positions in most accession countries are within the range of values for the structural current account positions suggested by the LSDV' and the Between estimator.

Table 6. Current Account Positions in 2002

\begin{tabular}{lcccc}
\hline & $\begin{array}{c}\text { Actual current } \\
\text { account }\end{array}$ & Fixed effect & \multicolumn{2}{c}{ Structural values } \\
\cline { 4 - 5 } Cyprus & -5.5 & -2.5 & LSDV & between \\
Czech Republic & -6.5 & 0.2 & -4.6 & -0.3 \\
Estonia & -12.4 & -1 & -9.8 & -4.5 \\
Hungary & -4 & 0.5 & -3.5 & -5.8 \\
Latvia & -7.8 & -0.3 & -9.7 & -6.1 \\
Lithuania & -5.2 & -0.2 & -5.5 & -8.5 \\
Malta & -3.8 & 0 & -4.4 & -6 \\
Poland & -3.5 & 0.2 & -2.4 & -4.6 \\
Slovak Rep. & -8.1 & 1.4 & -7.8 & -5.2 \\
Slovenia & 1.7 & 1.5 & 0.3 & -9.2 \\
\hline
\end{tabular}




\section{Performance of the model}

We now turn to discussing the performance of the model for our set of accession countries and OECD countries. In particular, we attempt to assess whether actual current account positions among these countries are consistent with the structural current accounts implied by our model. Figures 2 and Figure 3 show the actual current accounts and our two preferred estimated structural current account positions, i.e. those from the between estimator and from the LSDV' estimator, for

Figure 2. Historical Performance in the New EU Member States
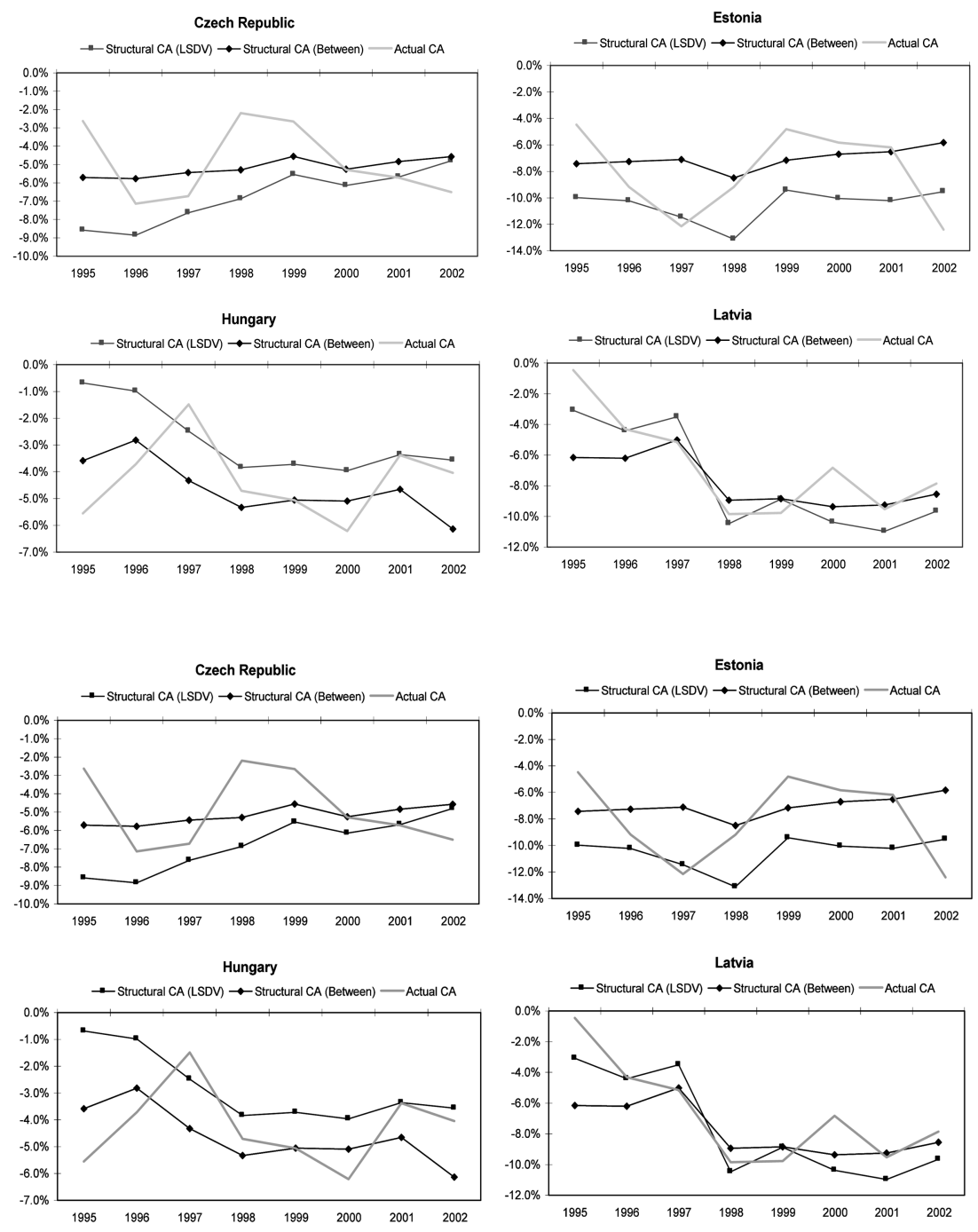
Figure 3. Historical Performance in Selected OECD Countries
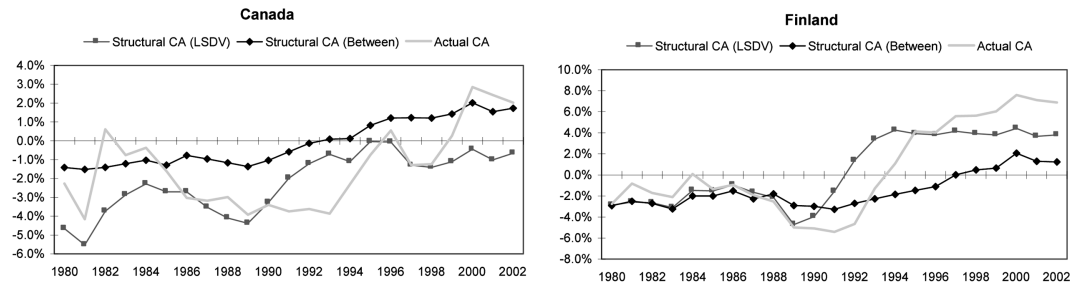

France

Ireland
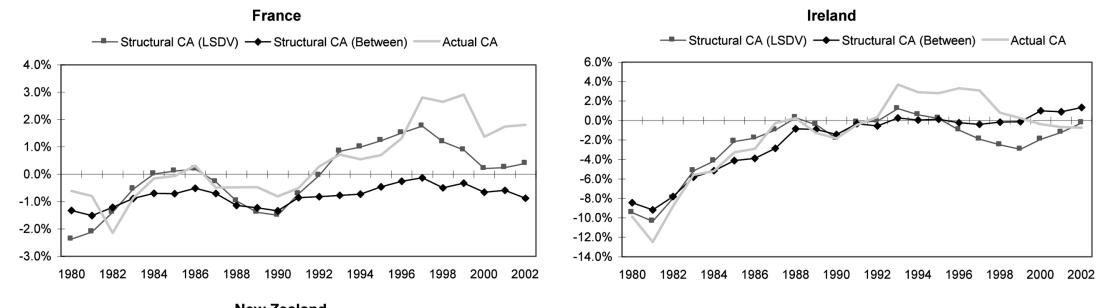

New Zealand
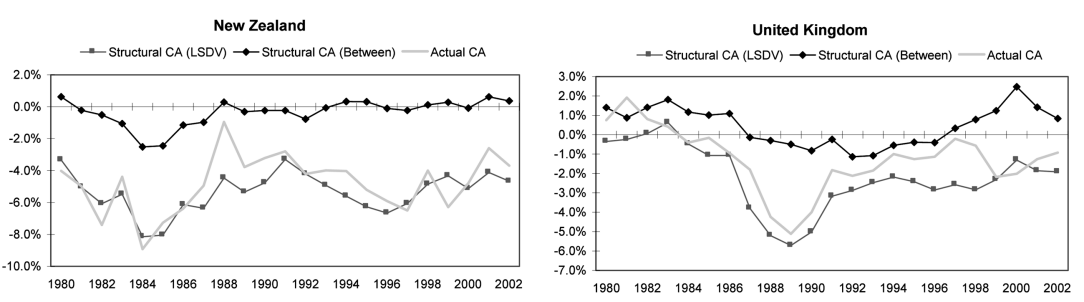

the ten new EU member states for 1995-2002 and a representative sub-sample of OECD/accession countries, respectively, for 1980-2002. A number of important conclusions can be drawn from the figures. First, the performance of the empirical model is good for most of the countries. This indicates that the theoretical model captures the most important elements to explain the current account dynamics for a relatively diverse set of countries of accession and OECD countries.

Second, the different empirical methods of the structural current account yield very similar estimates within most countries, underlining the robustness of the empirical model when using different methodologies. Two exceptions among OECD countries are New Zealand and the UK (Figure 3). For these two countries, the difference between the structural current account positions based on the withinestimator versus the between-estimator is quite sizeable. The reason for this large gap is the relatively large fixed effect for these two countries, indicating that in these two cases the variables included in the model do not explain well the level of the current account deficits, though they capture well their dynamics over time. For the new EU member states, however, fixed effects are mostly small, underlining the relevance of the included variables in the model. Third, these countries experienced 
very similar trends in the structural and observed current accounts. A common characteristic is that the estimated structural current account positions often declined, i.e. became more negative, initially in the mid-1990s, but then stabilized over the past five years. The main factor behind this trend has been the significant increase in investment ratios in those countries between the mid- and late 1990s, often coupled with a deterioration of fiscal positions, both of which have contributed to a decline in the structural current accounts. Fast growth and ensuing convergence towards OECD countries in more recent years then led to a stabilization of many countries' structural current account positions. Poland, Slovenia and the Slovak Republic provide examples for this trend.

Fourth, an important implication of the model is that actual current account positions in many new EU member states were, as of 2002, not out of line with fundamentals. Only for the Czech Republic, Estonia and Cyprus does the model imply that actual current account deficits are currently larger than there structural ones. Therefore, although actual current accounts in the past were rather volatile and frequently deviated substantially from their structural positions, it is striking that in 2002 most current accounts of these countries appear to be in line with what is suggested by our intertemporal model. Note that this result arises despite substantial deficits, mostly above $-4 \%$ of GDP and follows from the large potential of the new EU member states to catch up with OECD countries.

Finally, it is worthwhile noting that there are significant differences in structural current account positions across these countries. They range from large deficits in countries such as Estonia, Latvia and the Slovak Republic to countries whose current accounts are much closer to balance such as Slovenia and Poland. This confirms that also among catching up countries, just as for OECD countries, there are substantial differences in the degree of convergence achieved so far and economic fundamentals.

\section{Conclusion}

The present paper has developed an intertemporal model of the current account in order to derive structural current account positions for OECD and new EU accession member states. This model augments the standard ICA model with two key features. First, there are two categories of agents instead of one ("liquidity constrained" and "Ricardian"), allowing for fiscal deficits to play a role, in accordance with stylized facts and common findings of the empirical literature. Second, the model 
assumes that the behaviour of Ricardian agents exhibits some habit persistence. This second feature accounts for the high degree of sluggishness observed in current account positions and motivates the use of a dynamic model, as is now common in the empirical literature. A reduced form is derived and taken to the data in a panel of 33 OECD and Eastern European transition economies, using annual data.

Different estimators are presented in the empirical section (within, IV and GMM) and sensitivity tests are conducted, showing that the results are mostly robust across estimators and across countries. Our empirical model provides a parsimonious specification of the current account including the lagged current account, the change in net output, income per head, private investment and the government budget balance.

Moreover, we derive structural current account positions from the dynamic model and compare it with the results of a between estimation. We find that the fiscal balance, the relative income and relative investment positions determine the current account in the medium term. It implies that countries with a lower income per head and a higher investment ratio tend to have larger current account deficits. Moreover, the fiscal balance of a country is positively related to current account positions. Overall, we find that the actual current account developments for 19952002 are in line with structural current account positions.

Considering the new EU member states, we find that actual current account balances were close to their structural current account positions as of 2002. This suggests that from an intertemporal perspective, it may be perfectly rational for these countries to run deficits of such magnitude. Nevertheless, one needs to underline that this does not necessarily rule out the possibility of a sharp balance of payments adjustment due to other reasons not included in the model. In particular, the model does not consider liquidity issues, i.e. whether countries will continue to be able to finance their current account deficits, which are potentially crucial but constitute a different exercise. Combining the two perspectives of liquidity and of solvency of current account positions is a challenging issue that may be tackled by future research.

\section{Acknowledgments}

We would like to thank for comments and suggestions Giancarlo Corsetti, Rebecca Driver, Michael Evers, Louis G. Kuijs, Philip Lane, Adalbert Winkler and 
seminar participants at the European Central Bank and at the 2005 Annual Meeting of the American Economic Association. The views expressed in the paper are those of the authors and do not necessarily reflect those of the European Central Bank.

Received 19 July 2005, Accepted 12 December 2005

\section{References}

Abel, Andrew B. (1990), "Asset Prices under Habit Formation and Catching up with the Joneses," American Economic Review, Papers and Proc., 80(2), 38-42.

Anderson, T.W. and Cheng Hsiao (1982), "Formulation and Estimation of Dynamic Models using Panel Data" Journal of Econometrics, 18, 47-82.

Arellano, Manuel and Stephen Bond (1991), "Some Tests of Specification for Panel Data: Monte Carlo Evidence and an Application to Employment Equations," Review of Economic Studies, 58, 277-297.

Bond, Steven (2002), "Dynamic Panel Data Models: A Guide to Micro Data Methods and Practices," cemmap working paper 09/02, IFS/UCL, London.

Bussière, Matthieu, Georgios Chortareas and Rebecca L. Driver (2003), "Current Accounts, Net Foreign Assets and the Implication of Cyclical Factors," Working Paper 173, Bank of England.

Bussière, Matthieu and Marcel Fratzscher (2002), "Towards a New Early Warning System of Financial Crises", ECB Working Paper 145, forthcoming in Journal of International Money and Finance.

Bussière Matthieu, Marcel Fratzscher and Gernot Müller (2004), "Current Account Dynamics in OECD and EU Acceding Countries: an Intertemporal Approach", ECB Working Paper 311.

Campbell, John Y. and John H. Cochrane (1999), "By Force of Habit: A ConsumptionBased Explanation of Aggregate Stock Market Behavior", Journal of Political Economy, 107(2), 205-251.

Campbell, John Y. and N. Gregory Mankiw (1991), "The Response of Consumption to Income - A Cross-Country Investigation," European Economic Review, 35, 723-767.

Chinn, Menzie D. and Eswar S. Prasad (2003), "Medium-term Determinants of Current Accounts in Industrial and Developing Countries: An Empirical Exploration," Journal of International Economics, 59, 47-76.

Debelle, Guy and Hamid Faruqee (1996), "What Determines the Current Account? A Cross-Sectional and Panel Approach," IMF Working Paper 96/58, International Monetary Fund, Washington.

Galí, Jordi, J. David Lopez-Salido and Javier Valles (2002), "Understanding the Effects of Government Spending on Consumption," mimeo, UPF.

Glick, Reuven and Kenneth Rogoff (1995), "Global versus country-specific productivity 
shocks and the current account," Journal of Monetary Economics, 35, 159-192.

Gruber, Joseph W. (2002), "Productivity Shocks, Habits, and the Current Account", International Finance Discussion Papers 733, Washington: Board of Governors of the Federal Reserve System.

Kyung So Im, M Hashem Pesaran and Yongcheol Shin (2003), "Testing for unit roots in heterogenous panels", Journal of Econometrics, 115 (July 2003), pp.53-74.

Isard, Peter, Hamid Faruqee, G. Russell Kincaid and Martin Fetherston (2001), "Methodology for Current Account and Exchange Rate Assessments," IMF Occasional Paper 209, International Monetary Fund, Washington.

Kiviet, Jan F. (1995), "On Bias, Inconsistency, and Efficiency of various Estimators in Dynamic Panel Data Models", Journal of Econometrics, 68, 53-78.

Levin, Andrew, Chien-Fu Lin and Chia-Shang James Chu (2002), "Unit Root Tests in Panel Data: Asymptotic and Finite-Sample Properties", Journal of Econometrics, 108, 1-24.

Milesi-Ferretti, Gian Maria and Assaf Razin (1998), "Current Account Reversals and Currency Crisis-Empirical Regularities," IMF Working Paper 98/89, International Monetary Fund, Washington.

Nickell, Steven (1981), "Biases in dynamic models with fixed effects," Econometrica, 49, 1417-1426.

Obstfeld, Maurice and Kenneth Rogoff (1995), "The Intertemporal Approach to the Current Account," in Handbook of International Economics, vol. III, Elsevier, Gene Grossmann and Kenneth Rogoff (eds.).

Obstfeld, Maurice and Kenneth Rogoff (1996), Foundation of International Macroeconomics, MIT Press, Cambridge M.A.

Sachs, Jeffrey (1981), "The Current Account and Macroeconomic Adjustment in the 1970s," Brookings Papers on Economic Activity, 1, 201-282.

Sachs, Jeffrey (1982), "The Current Account in the Macroeconomic Adjustment Process," Scandinavian Journal of Economics, 84, 147-159.

Sheffrin, Steven M. and Wing Thye Woo (1990), "Present Value Tests of an Intertemporal Model of the Current Account", Journal of International Economics, 29, 237-253.

Ventura, Jaume (2003), "Towards a Theory of Current Accounts", The World Economy, 26(4), p.483-512. 